INTERNATIONAL JOURNAL OF PUBLIC DEVOTION

e-ISSN: 2614-6762 dan p-ISSN: 2614-6746

Volume 3 Number 1 . July 2020

(c) (i) (8) This work is licensed under

a Creative Commons Attribution-NonCommercial 4.0 International License.

\title{
Pendampingan Penulisan Penelitian Tindakan Kelas Pada Guru Mi Miftahul Ulum Di Tumpeng Bondowoso
}

\author{
Delora Jantung Amelia ${ }^{1}$, Frendy Aru Fantiro ${ }^{2}$ \\ Universitas Muhammadiyah Malang ${ }^{1}$, Universitas Muhamamdiyah Malang ${ }^{2}$ \\ delorajantung@umm.ac.id ${ }^{1}$, Frendy_aru@umm.ac.id ${ }^{2}$
}

\section{Kata Kunci :}

Pendampingan; Penelitian

Tindakan Kelas

\begin{abstract}
ABSTRAK
Banyaknya permasalahan yang dihadapi guru MI Miftahul Ulum di Tumpeng Bondowoso baik berupa nilai peserta didik yang tidak sesuai, inovasi pembelajaran yang belum bisa diterima peserta didik, permasalahan sosial yang dialami peserta didik dan masih banyak yang lainnya. Dengan adanya problematika-prolematika tersebut kegiatan pembelajaran tidak berjalan dengan baik. Dosen-dosen PGSD UMM bekerja sama dengan MI Miftahul Ulum bekerjasama untuk mengatasi problematika terssebut dengan jalan pengabdian kelompok merupakan suatu program yang mencoba dan mengatasi kendala yang ada. Melalui pendampingan pembuatan Penelitian Tindakan Kelas maka dapat meningkatkan profesionalisme guru di MI Miftahul Ulum Tumpeng Bondowoso. Adapun kegiatan pendampingan yang dilakukan dimulai dari kegiatan workshop penyusunan Pelitian Tindakan Kelas, pendampingan pembuatan proposal, pengaplikasiaan proposal dan menyusnan analisis data yang diperoleh dari kegiatan pendampingan. Secara keseluruhan dari kegiatan pendampingan penyusunan penelitian tindakan kelas di MI Miftahul Ulum di Tumpeng Bondowoso dapat berjalan dengan lancar dan baik. Kegiatan pendampingan ini diikuti oleh seluruh guru yang berjumlah 12 orang yang mana kegiatan di mulai dari workshop pemberian materi penelitian tindakan kelas kemudian dilankutkan dengan analisis problematika yang ada di dalam kelas dan dilanjutkan dengan penyusunan proposal penelitian tindakan kelas setelah penyusunan proposal selesai dilanjutkan dengan penerapan penelitian tindakan kelas di dalam kelas dan penyusunan analisis data yang diperoleh di dalam kelas. Dengan adanya kegiatan pendampingan ini guru menjadi paham dan mengerti akan kegiatan penelitian tindakan kelas yang ada di dalam kelas. Dengan menerapkan penelitian tindakan kelas dapat mengatasi problematika yanga ada di dalam kelas dengan dukungan teori dan jurnal.
\end{abstract}


Keywords :

Mentoring; classroom action research

\begin{abstract}
There are many problems faced by MI Miftahul Ulum teachers in Tumpeng Bondowoso, both in the form of students' scores that are not appropriate, learning innovations that cannot be accepted by students, social problems experienced by students and many others. With these problems, learning activities are not going well. UMM PGSD lecturers in collaboration with MI Miftahul Ulum collaborate to overcome these problems by means of group service which is a program that tries and overcomes existing obstacles. Through assistance in making Classroom Action Research, it can improve teacher professionalism at MI Miftahul Ulum Tumpeng Bondowoso. The mentoring activities carried out were started from workshops on the preparation of Classroom Action Research, assistance in making proposals, application of proposals and compiling data analysis obtained from mentoring activities. Overall, the assistance activities for the preparation of classroom action research at MI Miftahul Ulum in Tumpeng Bondowoso can run smoothly and well. This mentoring activity was attended by all 12 teachers, where activities started from workshops providing classroom action research material then continued with problematic analysis in the classroom and continued with the preparation of classroom action research proposals after the preparation of the proposals was completed followed by the application of action research. class in the classroom and compilation of data analysis obtained in the classroom. With this mentoring activity, the teacher understands and understands classroom action research activities in the classroom. By implementing classroom action research, you can solve problems in the classroom with the support of theories and journals.
\end{abstract}

\section{PENDAHULUAN}

Peningkatan mutu pendidikan dapat tercapai dengan baik jika guru dapat mengidentifikasi dengan baik permasalahan yang terjadi di kelas. Penyelesaian berbagai masalah yang terjadi di dalam kelas dapat diselesaikan dengan baik dengan melakukan kegiatan Penelitian Tindakan Kelas. Guru merupakan suatu profesi yang sangat starategis sekali. Guru tidak hanya menguasai bidang yang sesuai dengan bidangnya untuk mengajar peserta didik akan tetapi guru juga harus dituntut harus kreatif, inovatif serta inspiratif dalam kegiatan mengajar di dalam kelas. Sebagai seorang guru tidak hanya dituntut hanya mengajar saja akan tetapi seorang guru harus dapat menambah ilmunya baik berupa ilmu pengetahuan sesuai dengan bidangnya dan ilmu pengetahuan untuk megatasi segala proplema di dalam kelas. Dalam rangka pengembangan suatu professional guru tidak bisa lepas dari suatu kegiatan akademik suatu penelitian (Sudiana, 2013). Oleh karenanya seorang guru harus bisa menyelesaikan problematika yang terjadi di dalam kelas dalam suatu penelitian Tindakan kelas, Wijaya, 2009 penelitian Tindakan kelas adalah suatu penelitian yang dilakukan oleh guru.

Sebagai seorang pendidik guru pasti memiliki permasalahan di dalam kelas baik berupa nilai peserta didik yang kurang memuaskan, inovasi pembelajaran yang terbaru, permasalahan social yang terjadi antar peserta didik. permasalahan-permaslahan di atas dapat diselesaikan atau dituangkan dalam suatu kegiatan penelitian tindakan kelas (PTK). Undang-undang No 20 Tahun 2003 tentang system pendidikan menjelaskan bahwa pendidikan berfungsi untuk dapat mengembangkan watak serta peradapan bangsa yang bermartabat untuk dapat mencerdaskan kehidupan bangsa yang bertujuan untuk mengembangkan potensi peserta didik agar menjadi manusia yang beriman dan bertakwa. 
Melalui Penelitian Tindakan Kelas masalah-masalah dalam pendidikan baik berupa pembelajaran ataupun masalah social dapat dituntaskan dengan baik. Dengan adanya kegiatan Penelitian Tindakan Kelas dapat menciptakan iklim belajar yang dikehendaki oleh guru. Sejalan dengan itu upaya perbaikan kualitas pembelajaran merupakan suatu inisiatif dan keinginan sorang guru (Tantra, 2005). Jika guru tidak menginginkan maka hal tersebut akan sulit dilakukanpenelitian Tindakan kelas merupakan suatu kegiatan yang mampu meningkatkan hasil belajar peserta didik (Kuo, 2015). Hal itu sejalan dengan Mills yang menyatakan bahwa penelitian Tindakan kelas merupakan suatu tujuan memperoleh informasi dalam menghasilkan perubahan (Hong \& Lawrence, 2011). Penekanan bahwa penelitian tindakan digunakan sebagai upaya pengentasan masalah-masalah riil, untuk meningkatkan efektifitas. PTK memiliki keunggulan dalam membantu guru mengembangkan kegiatan pembelajaran (Hine, 2013). Akan tetapi permasalahan-permasalahan yang dihadapi guru yang diselesaikan dengan PTK juga ditolak menyatahkan beberapa orang mengkritik bahwa penelitian tindakan adalah penelitian informal karena para guru bukanlah peneliti akademis, diyakini secara luas bahwa penelitian tindakan sangat sesuai untuk pendidikan karena tujuan utamanya adalah untuk membantu guru untuk dapat memecahkan masalah yang terjadi di dalam kelas (Hien, 2009).

MI Miftahul ulum Tumpeng merupakan satuan pendidikan setingkat Sekolah Dasar yang berlokasi di Jalan Trunojoyo No 35 Desa Tumpeng, Bondowoso. Sekolah ini merupakan sekolah Plus Islami yang mengembangkan SDM yang berkualitas di bidang IPTEK dan IMTAQ yang mana memiliki 6 kelas untuk kegiatan pembelajaran mulai dari kelas 1 sampai dengan kelas 6. Selama ini sekolah tersebut belum melaksanakan penelitian tindakan kelas pada kegiatan pembelajaran di sekolah. Sebagian besar guru-guru belum memahami akan Penelitian Tindakan Kelas, dengan adanya pendampingan penyusunan Penelitian Tindakan Kelas diharapkan dapat membantu guru-guru untuk dapat mengatasi permaslahan-permasalahan yang terjadi di sekolah, guru-guru dapat memiliki.

Banyaknya permasalahan yang dihadapi guru baik berupa nilai peserta didik yang tidak sesuai, inovasi pembelajaran yang belum bisa diterima peserta didik, permaslahan sosial yang dialami peserta didik dan masih banyak yang lainnya. Pengabdian kelompok merupakan suatu program yang mencoba dan mengatasi kendala yang ada. Melalui pendampingan pembuatan karya ilmiah Penelitian Tindakan Kelas maka dapat meningkatkan profesionalisme guru di MI Miftahul Ulum Tumpeng Bondowoso. Perkembangan pendidikan akhir-akhir a telah menuntut pemanfaatan penelitian dalam praktek nyata pengajaran. Pada kenyataannya, sampai saat ini, pemanfaatan hasil-hasil penelitian tidak begitu saja dapat secara langsung mempengaruhi praktik pembelajaran yang dilakukan di kelas (Dantes: 2006).

Solusi yang ditawarkan Pendampingan Penelitian Tindakan Kelas dilakukan dengan workhshop terlebih dahulu yang berisikan tentang pemaparan pembuatan proposal PTK, pembuatan proposal PTK penekanan permasalahan-permasalahan yang terjadi di dalam kelas mulai dari kelas I- kelas VI. Setelah permasalahan-permasalahan terpaparkan dengan baik solusi-solusi yang sesuai dengan permasalahan di dalam kelas dipaparkan ke dalam proposal pembuatan Penelitian Tindakan Kelas. Pembuatan proposal tidakan di dalam kelas dirancang untuk mengatasi permasalahan-permasalahan di dalam kelas. Adapun kegiatan $\mathrm{I}_{\mathrm{b}} \mathrm{M}$ Pendampingan Penelitian Tindakan Kelas di MI Miftahul Ulum Tumpeng Bondowoso adalah sebagai berikut:. 1) Workshop Pendampingan Penelitian Tindakan Kelas Di MI Miftahul Ulum Tumpeng Bondowoso. Kegiatan diawali dengan proses sosialisasi program pengabdian. Kemudian dilanjutkan dengan pemberian materi tentang pembuatan proposal Penelitian Tindakan Kelas. Materi yang diberikan mencakup tentang bagaimana mencari permasalahan di dalam kelas yang dirasa sangat penting untuk diselesaikan, cara mengatasi permasalahan yang sesuai dengan teori atau sumber rujukan yang jelas. Pada akhir kegiatan diharapkan peserta atau Bapak/Ibu guru mampu membuat sebuah penelitian Tindakan. kelas yang mana akan diimplementasikan di dalam kelas untuk mengatasi permasalahan yang ada. 2) guru Menghadiri acara workshop pendampingan pembuatan Penelitian Tindakan Kelas (PTK) yang diawali dengan kegiatan sosialisasi kegiatan pengabdian dan dilanjutkan materi pembuatan proposal PTK. Adapun materi yang harus dipahami adalah mengenai pembuatan proposal antara lain, pengidentifikasihan permasalahan-permasalahan yang terjadi di dalam kelas. Mencari solusi untuk mengatasi permasalahan dengan teori, membuat judul proposal yang sesuai dengan aturan-aturan, membuat proposal Penelitian Tindakan Kelas, mengimplementasikan proposal Penelitian Tindakan Kelas. 


\section{METODE PELAKSANAAN}

Pengabdian ini dilakukan untuk penyusunan program pendampingan Penulisan Penelitian Tindakan Kelas yang dilaksanakan di MI Miftahul Ulum Tumpeng Bondowoso. Peserta pendampingan ini berjumlah 12 orang yang mana Adapun langkah-langkah pendampingan sebagai berikut:

\section{Langkah-langkah Pelaksanaan Pendampingan: \\ 1. Pelaksanaan Workshop}

Kegiatan diawali dengan proses sosialisasi program pengabdian. Kemudian dilanjut-kan dengan pemberian materi tentang pembuatan penelitian tindakan kelas. Materi yang diberikan mencakup tentang menemukan masalah-masalah yang ada di dalam kelas, kemudian solusi untuk menyelesaikan masalah sesuai dengan rujukan teori. Setelah menemukan permasalahan pada kegiatan workshop juga diberikan materi-materi terkait penulisan penelitian tindakan kelas (PTK).

Menghadiri acara workshop pendampingan Penelitian Tindakan Kelas yang diawali dengan kegiatan sosialisasi kegiatan pengabdian dan dilanjutkan materi pembuatan PTK, Adapun materi yang harus dipahami adalah mengenai pembuatan proposal penelitian tindakan kelas, dan materi menerapkan PTK serta komponen-komponen pendukung, untuk membuat proposal PTK guru juga melakukan analisis kebutuhan, meliputi analisis karakteristik siswa, kurikulum tematik, materi dan ketersediaan bahan materi.

\section{Pendampingan Penyusunan PTK}

Program pengabdian ini setelah melaksanakan workshop tentang penulisan tindakan kelas dilanjutkan dengan pendampingan proposal penelitian tindakan kelas. Pendampingan pembuatan proposal yang mana pendampingan tidak hanya dilaksanakan secara tatap muka akan tetapi juga dilaksanakan melalui whatsapp maupun email. Pada tahap ini guru menyusun proposal penelitian tindakan kelas yang sesuai dengan rancangan yang telah disepakati, setelah proposal dinilai sudah benar maka proposal tersebut dikonsultasikan kepada tim pengabdi. Jika ada proposal yang dinilai belum sesuai dengan kesepakatan maka guru akan merevisi proposal tersebut.

\section{Pendampingan Pengimplementasiaan PTK}

Program pendampingan Penelitian Tindakan Kelas yang telah dibuat berupa proposal akan diimplementasikan pada kegiatan pembelajaran di dalam kelas. Saat kegiatan pengimplementasiaan, guru akan didampingi oleh tim pengabdian. Kegiatan ini akan didokumentasikan dalam bentuk rekaman video. Akhir pembelajaran, tim pengabdian dan guru mengevaluasi bersama-sama terrhadap efektivitas pelaksanaan pengaplikasihan proposal Penelitian Tindakan Kelas. Guru mengimplementasikan proposal Penelitian tindakan Kelas yang telah dibuat dan diterapkan pelaksanaanya di dalam kelas. Sebelum guru mengimplementasikan proposal PTK guru menyiapkan alat dan bahan yang akan dibutuhkan.

\section{Tahapan Evaluasi dan refleksi}

Pada tahap ini dilakukan evaluasi terhadap pelaksanaan Pendampingan Penelitian Tindakan Kelas, yang yang telah diimplementasikan dalam proses kegiatan di dalam kelas. Pada kegiatan ini juga dilaksanakan refleksi terhadap seluruh kegiatan yang telah dilaksanakan. Refleksi diawali dengan tanya jawab, dan diskusi dengan guru sebagai bahan pertimbangan atau rekomendasi pada kegiatan selanjutnya.

\section{HASIL DAN PEMBAHASAN}

Pendampingan penulisan Penelitian Tindakan Kelas merupakan program yang memanfaatkan kemampuan untuk berfikir ilmiah, kritis, inovatif dalam pengembangan ilmu dan teknologi yang mengalami perkembangan saat ini. Penelitian Tindakan Kelas merupakan solusi yang bagus yang harus diterapkan di dalam kelas untuk mengatasi berbagai permasalahan yang terjadi di dalam kelas. Berdasarkan hal tersebut tim pelaksanaan pengabdian, terdiri dari dosen bidang ilmu Pendidikan Guru 
Sekolah Dasar guru kelas, dan Bidang keolahragaan yang sangat sesuai dengan bidang yang akan diusulkan terutama terkait pendampingan pembuatan Penelitian Tindakan Kelas yang akan diikuti seluruh guru MI Miftahul Ulum Tumpeng Bondowoso. Pada tabel 1 disajikan uraian tugas dari pelaksana kegitan pengabdian kepada masyarakat.

Tabel 1. Uraian Tugas Pelaksana Kegiatan

\begin{tabular}{|c|c|c|c|}
\hline No & Nama & Jenis Kegiata & \\
\hline 1. & Frendy Aru Fantiro, M.Pd & $\begin{array}{l}\text { Workshop Cara Megidentifikasi } \\
\text { Permasalahan-permasalahan yang } \\
\text { terjadi di dalam kelas }\end{array}$ & $\begin{array}{l}\text { Pendampingan } \\
\text { Penulisan }\end{array}$ \\
\hline 2. & Delora Jantung Amelia, M.Pd & $\begin{array}{l}\text { Workshop pembuatan proposal } \\
\text { Penelitian Tindakan Kelas }\end{array}$ & $\begin{array}{l}\text { enelitian Indakan } \\
\text { Kelas }\end{array}$ \\
\hline
\end{tabular}

Target dan luaran di atas sesuai dengan tujuan penampingan yang nantinya akan memberikan dampak pada:

1. Memberikan solusi terhadap permasalahan-permasalahan yang terjadi di sekolah

2. Meningkatkan kreativitas dan inovasi pada kegiatan pembelajaran.

Pada kegiatan pengabdian pendampingan penulisan penelitian tindakan kelas pada guru MI di Tumpeng Bondowoso kegiatan dibagi dalam beberapa kegiatan yang dipaparkan sebagai berikut:

1. Pelaksanaan Rapat

Sebelum melaksanakan pengabdian kepada masyarakat tim pengabdi melakukan rapat kordinasi yang dilakukan melalui zoom meeting yang mana dengan paparan sebagai berikut:

a. Rapat Kordinasi Perancangan Jadwal Kegiatan

Pada tanggal 17 Juli 2020 diadakan rapat terkait teknis pelaksanaan pendampingan penyusunanPenelitian Tindakan Kelas. Rapat ini lakukan guna merancang serangkaian kegiatan yang akan dilakukan. Selain itu juga dilakukan penyelesaiaan administratif berkenaan dengan kegiatan pendampingan.

b. Rapat Kordinasi Teknis Pelaksanaan Dengan Kepala Sekolah

Pada Tanggal 22 Juli 2020 dilakukan rapat kordinasi dengan perwakilan MI Miftahul Ulum Tumpeng dilakukan rapat kordinasi untuk perancangan pelaksanaan kegiatan pendampingan penyusunan Penelitian Tindakan Kelas.

2. Pelaksanaan Rancangan Pendampingan Penyusunan Penelitian Tindakan Kelas

Penyelenggaraan penyusunan Penelitian Tindakan Kelas dimulai dari kegiatan workshop, yang mana kegiatan workshop dimulai dari Tim pengabdi masyarakat yang dilakukan oleh dosen PGSD UMM yang terdiri dari Frendy Aru Fantiro dan Delora Jantung Amelia. Kegiatan workshop ini dimulai dari perencanaan penyususnan materi workshop yang disusun oleh tim pengabdian yang berjumlah 2 orang dan dibantu oleh mahasiswa kemudian pemateri satu persatu memaparkan materi yang telah disiapkan, setelah pemaparan materi, dibuatlah penyusunan problematika pembelajaran yang dialami di dalam kelas, setelah itu dilanjutkan dengan penyusunan judul, setelah penyusunan judul dilakukan dibukalah sesi tanya-jawab yang diperuntukan untuk peserta yang belum pahan akan penjelasan yang telah dipaparkan. Pelaksanaan workshop memberikan pengalaman, wawasan dan pemahaman dalam mengatasi problematika di dalam kelas yang harus diselesaikan dengan penerapan model pembelajaran, metode dan penerapan media pembelajaran.

\section{Pendampingan Penyusunan Penelitian Tindakan Kelas}

Pendampingan dimulai dari kegiatan workshop yang mana rangakaian kegiatannya pembahasan tentang penyusunan PTK dimulai dari menganalisis permasalahan, penyusunan judul yang sesuai dan dilanjtkan sistematika penyusunan PTK setelah itu dilanjutkan dengan penyusunan pembuatan PTK yang mana hasil penampingan dijelaskan dalam pemaparan di bawah ini: 
a. Pendampingan 1

Pendampingan penyusunan dilakukan pada tanggal 25 Agustus 2020 pendampingan pertama difokuskan dalam penyusunan pembuatan judul dan proposal PTK. Adapun kemajuan peserta setelah dilakukan workshop sebagai berikut:

1) Peserta sudah dapat memaparkan problematika permasalahan yang dihadapi di dalam kelas

2) Peserta dapat menyusun judul yang sesuai dengan problematika yang dihadapi di dalam kelas.

3) Peserta sudah memahami gambaran proposal PTK yang akan dikerjakan.

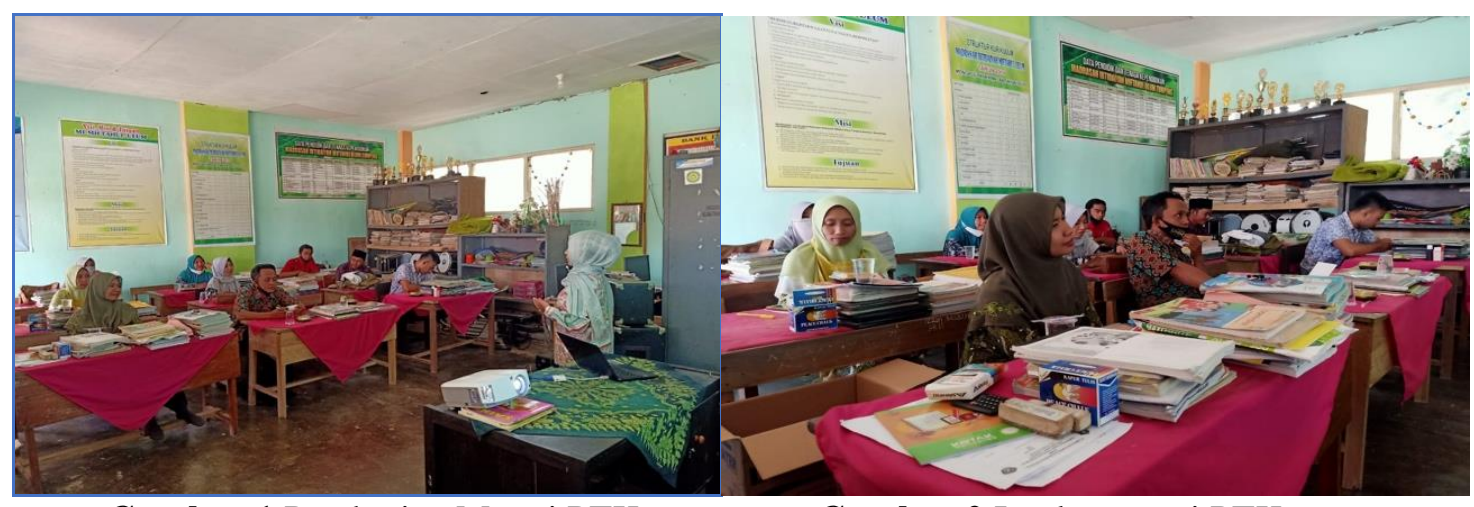

Gambar 1 Pemberian Materi PTK

Gambar 2 Implementasi PTK

Hasil dari pendampingan 1 peserta sudah dapat menganalisis problematika yang terjadi di dalam kelas dan pemberian solusi yang sesuai dengan kebutuhan dengan dukungan teori dan jurnal. Dari hasil pendampingan 1 peserta juga sudah dapat menyusun proposal PTK yang mana nantinya akan diimplementasikan pada kelas masing-masing.

\section{b. Pendampingan 2}

Pendampingan ke dua dilakukan via zoom yakni tanggal 2 September pendampingan ini dimaksudkan untuk memberikan komentar dan masukan terkait proposal PTK yang sudah dibuat oleh guru-guru MI dan dapat dipaparkan hasil dari kegiatan pendampingan ke dua yaitu:

1) Rata-rata pembuatan prosal penelitian Tindakan kelas sudah terlaksana dengan baik akan tetapi dalam proses penulisan masih kurang memenuhi kaidah ilmiah.

2) Pada bab 1 latar belakang analisis permasalahan masih belum terpaparkan dengan jelas dan cara mengatasi permasalahan masih belum dikaitkan dengan dukungan teori dan jurnal.

3) Dari segi penulisan masih banyak rujukan yang masih belum memuat sumber rujukan dengan jelas.

Dari hasil pendampingan ke 2 peserta mendapat revieu hasil penulisan PTK yang mana ada beberapa yang perlu direvisi, setelah proses revisi sudah dilakukan maka diimplementasikan pada kegiatan di dalam kelas.

\section{c. Pendampingan 3}

Pada pendampingan 3 peserta sudah mulai menguji cobakan hasil proposal PTK kepada kelas yang diampu. Dari beberapa guru yang mengikuti dipilihlah satu guru yang terbaik dalam melaskan penerapan PTK di kelas yang diampu. Adapun rincian pelaksanaan kegiatan pelaksanaan PTK dimulai dari guru mengajak siswa mengaitkan pengetahuan yang sudah dimilikinya kemudian guru memutarkan video yang sudah disiapkan. Guru menjelaskan media video yang dibawa sebelumnya kemudian guru menerangkan materi yang sesuai denga nisi video. Guru membentuk siswa dalam beberapa kelompok dan siswa menganalisis kejadian-kejadian kenampakan alam yang terjadi di dalam video. Guru memberikan soal dalam bentuk individu dan kelompok. Guru melihat peningkatan hasil belajar yang diperoleh oleh peserta didik dan mengalami peningkatan yang tinggi,

Pendampingan penyusunan Penelitian Tindakan kelas membantu guru dalam mengatasi problematika yang ada di dalam kelas yang diatasi dengan dukungan teori dan jurnal. Dengan adanya peneran PTK yang mana dilaksanakan minimal dua siklus dapat meningkatkan problematika yang dialami disekolah baik yang berhubungan dengan nilai yang kurang dari KKM, kurangnya keefektivan dalam kegiatan 
pembelajaran, rendahnya minat belajar dan motivasi siswa. Pada mulanya guru-guru belum mengetahui dan belum tahu caranya membuat penelitian Tindakan kelas dengan adanya pendampingan penyusunan pembuatan penelitian Tindakan kelas yang dilakukan selama kurang lebih tiga bulan dapat membuat guru-guru paham akan kegiatan penelitian Tindakan kelas.

\section{KESIMPULAN DAN SARAN}

\section{Kesimpulan}

Secara keseluruhan dari kegiatan pendampingan penyusunan penelitian tindakan kelas di MI Miftahul Ulum di Tumpeng Bondowoso dapat berjalan dengan lancer dan baik. Kegiatan di mulai dari workshop pemberian materi PTK kemudian dilankutkan dengan analisis problematika yang ada di dalam kelas dan dilanjutkan dengan penyusunan proposal PTK setelah penyusunan proposal selesai dilanjutkan dengan penerapan PTK di dalam kelas dan penyusunan analisis data yang diperoleh di dalam kelas. Pada mulanya guru-guru belum mengetahui akan pembuatan PTK dengan adanya kegiatan pendampingan ini guru menjadi paham dan mengerti akan kegiatan PTK yang ada di dalam kelas. Dengan menerapkan penelitian Tindakan kelas dapat mengatasi problematika yanga ada di dalam kelas dengan dukungan teori dan jurnal.

\section{Saran}

Saran pada kegiatan ini untuk dapat meningkatkan pemahaman para guru MI Miftahul Ulum di Tumpeng Bondowoso sesuai dengan kegiatan pendampingan penulisan maka perlu diuji cobakan secara maksimal untuk dapat menyelesaikan masalah pembelajaran di kelas. Kegiatan ini masih perlu dilanjutkan dengan pendampingan, pelatihan dan motivasi pelaksanaan PTK dengan menerapkan beberapa siklus.

\section{UCAPAN TERIMA KASIH}

Ucapan terimakasi kepada pihak-pihak yang telah membantu kegiatan pendampingan penyusunan Penelitian Tindakan Kelas di Miftahul Ulum Di Tumpeng Bondowoso. Ucapan terimakasi kepada pihak Yayasan yang sudah bersedia memberikan izin dalam melaksanakan pendampingan, kepala sekolah yang sudah memberikan waktu, tenaga dan tempat dalam pelaksanaan pendampingan dan guru-guru MI yang sudah mengikuti serangkaian kegiatan Penelitian Tindakan Kelas.

\section{DAFTAR PUSTAKA}

Dantes, N. (2006). Penelitian Tindakan Kelas: Konsep Dasar dan Prosedur Pelaksanaan dalam Jurnal Widya Laksana, Vol.6, No. 2, Agustus 2017155 Rangka Peningkatan Profesionalisme Guru. (Bahan Pelatihan Bagi Guru-Guru di Kabupaten Karangasem.

Hien, T.T.T. (2009). Why is action research suitable for education?. VNU Journal of Science, Foreign Languages 25 (2009) 97-106

Hine, G. S.C. (2013). The importance of action research in teacher education programs. Issues in Educational Research, 23(2), 2013: Special Issue

Hong, C.E., Lawrence, St.A. (2011). Action Research in Teacher Education: Classroom Inquiry, Reflection, and Data-Driven Decision Making. Journal of Inquiry \& Action in Education, 4(2)

Kuo, Nai-Cheng. (2015). Action Research for Improving the Effectiveness of Technology Integration in Preservice Teacher Education.i.e.: inquiry in education: Vol. 6: Iss. 1, Article 3. Retrieved

Sudiana, 2013. I Nyoman. 2013. Penelitian Tindakan Kelas makalah disampaikan dalam Pelatihan Penyusunan Proposal Tindakan Kelas bagi Guru-Guru Bahasa Indonesia

Tantra. D.K. 2005. Penelitian Tindakan Kelas (Makalah disampaikan dalam Workshop Menumbuhkan Komitmen Guru dan Pegawai SMA Negeri 4 Denpasar. 